\title{
Correction to: Local knowledge, global ambitions: IPBES and the advent of multi-scale models and scenarios
}

\author{
Noam Obermeister ${ }^{1}[$ (D)
}

Published online: 28 September 2018

(c) Springer Japan KK, part of Springer Nature 2018

\section{Correction to: Sustainability Science https://doi.org/10.1007/s11625-018-0616-8}

In the original publication of the article, Role and membership in IPBES of Interviewee D in Table 1 was published incorrectly. The correct Table 1 is provided.

Table 1 List of interviewees with their respective disciplinary background and role in IPBES

\begin{tabular}{|c|c|c|c|c|c|}
\hline Interviewee & Disciplinary background & Gender & Role and membership in IPBES & $\begin{array}{l}\text { Member of } \\
\text { phase } 2 \text { group }\end{array}$ & $\begin{array}{l}\text { At New- } \\
\text { Zealand } \\
\text { workshop }\end{array}$ \\
\hline A & STS scholar & $\mathrm{F}$ & Lead author of the GA & No & No \\
\hline B & Ecologist & M & Member of ILK taskforce & No & No \\
\hline $\mathrm{C}$ & Ecologist, ex-modeller & M & Contributor to ECA & No & No \\
\hline $\mathrm{D}$ & Land-use expert & $\mathrm{F}$ & Lead author of the LDRA & Yes & No \\
\hline $\mathrm{E}$ & Ecologist, modeller & M & $\begin{array}{l}\text { Lead author of the MAR and member of TSU on } \\
\text { Models and Scenarios }\end{array}$ & Yes & Yes \\
\hline $\mathrm{F}$ & Sustainability scientist & M & Lead author of the MAR & No & Yes \\
\hline G & Human geographer & $\mathrm{F}$ & Member of ILK taskforce & No & No \\
\hline $\mathrm{H}$ & Political scientist & $\mathrm{F}$ & Member of scenario and model group & Yes & Yes \\
\hline I & Anthropologist & M & Lead author of the GA and member of ILK taskforce & No & No \\
\hline $\mathrm{J}$ & Marine ecologist, modeller & $\mathrm{F}$ & Lead author of the MAR & Yes & Yes \\
\hline
\end{tabular}

GA global assessment, ECA Europe and Central Asia Assessment, LDRA land degradation and restoration assessment, TSU technical support unit, MAR methodological assessment report on scenarios and models

The original article can be found online at https://doi.org/10.1007/ s11625-018-0616-8.

Noam Obermeister

obermeister.noam@gmail.com

1 London, UK 